\title{
Anti-Pyretic Properties of Methanolic Bark Extracts of Terminalia brownii in Wistar Rats (Rattus novegicus)
}

\author{
Jane W Mbiri ${ }^{1 *}$, Sichangi Kasili², Wilton Mbinda ${ }^{3}$, Patrick D Kisangau² and Ngugi M Piero ${ }^{4}$ \\ ${ }^{1}$ Department of Biochemistry and Biotechnology, School of Pure and Applied Sciences, South Eastern Kenya University, Kenya \\ ${ }^{2}$ Department of Biology, School of Pure and Applied Sciences, South Eastern Kenya University, Kenya \\ ${ }^{3}$ Department of Physical Sciences, School of Pure and Applied Sciences, Karatina University, Kenya \\ ${ }^{4}$ Department of Biochemistry and Biotechnology, School of Pure and Applied Sciences, Kenyatta University, Kenya
}

\begin{abstract}
The conventional drugs used to manage fever are usually not affordable, not easily available and have adverse side effects. Alternative therapeutic agents, like medicinal plant derivatives, should therefore be developed because they have been reported to be more affordable, more readily available and have lesser side effects. Terminalia brownii is traditionally used to manage fever but this ethno-medicinal claim lacks scientific validation. The present study therefore evaluated the anti-pyretic activity of $T$. brownii in Wistar rats. Fresh bark samples of $T$. brownii were collected from Kitui County, Kenya. This study used 30 adult male Wister rats that were 2-3 months old and weighing 140-180 $\mathrm{g}$ was used for the experiments. Steam-distilled turpentine was the pyrogen used to induce pyrexia and Aspirin was used as the reference drug. The extract reduced the elevated rectal temperatures by between $1.15-$ $4.38 \%$ while aspirin reduced the elevated rectal temperatures by between $0.00-4.85 \%$. The present study showed a significant dose-dependent anti-pyretic activity of methanolic bark extracts of $T$. brownii hence validating its folklore use as a fever remedy.
\end{abstract}

Keywords: Anti-pyretic activity; Aspirin; Methanolic bark extracts; Terminalia brownii

\section{Introduction}

Microbial infections, body tissue damage, chronic diseases and graft rejection elevates the body temperatures beyond the normal range of between $36 \cdot 5-37.5^{\circ} \mathrm{C}$, leading to pyrexia or fever $[1,2]$. Cytokines such as tumor necrosis factor $\alpha$ and $\beta$ (TNF $\alpha$ and TNF $\beta$ ) and interleukins (IL-6, IL- $\alpha$ and IL- $\beta$ ) produced when the body is invaded by microorganisms or body tissues are damaged stimulates the conversion of arachidonic acid to prostaglandins, the major fever mediator, in the hypothalamus [3]. Prostaglandins in turn trigger the hypothalamus to produce responses that elevate the body temperatures [2]. Although pyrexia causes unnecessary suffering and discomfort, it is considered as a natural defense mechanism that creates an environment where infectious agent or damaged tissue cannot survive [4].

Non-Steroidal Anti-inflammatory Drugs (NSAIDs) are used in the management of pyrexia [5]. However, their use is declining due to their adverse gastrointestinal effects like bleeding, perforations and peptic ulcers [6]. These conventional drugs have also been reported to be unaffordable and less effective [7]. Continuous search for alternative therapeutic agents with much lesser adverse effects is therefore necessary. Naturally occurring plant-based derivatives are considered as better alternatives due to their lesser side effects, ready availability and inexpensive nature [8]. Herbal medicine is increasingly gaining popularity. Currently, approximately $25 \%$ of available synthetic drugs are formulated either directly or indirectly from medicinal plants [9].

Terminalia brownii [Combretaceae] is native in Kenya, Democratic Republic of Congo, Tanzania and Ethiopia [10]. The tree grows near rivers and wadies in dry areas and in moist savannas of semi-arid regions, thriving best on sandy loam soils [11]. T. brownii is used as a folklore remedy for jaundice, stomach ache, urogenital infections, malaria, gastric ulcers, epilepsy, cough, hepatitis and liver cirrhosis in different parts of Eastern and Central Africa [10]. Although T. brownii is used as a traditional remedy for fever, no studies have been conducted to validate this ethno-medicinal claim. The present study was therefore aimed at evaluating the anti-pyretic properties of methanolic bark extracts of T. brownii.

\section{Materials and Methods \\ Collection and preparation of plant materials}

With the help of a local herbalist, fresh bark materials were collected from Kitui County, Kenya. The samples were sorted, cleaned and packed in polythene bags and transported to the Biochemistry and Biotechnology laboratories at Kenyatta University (KU) for further processing. A voucher specimen of the tree species was collected and botanically authenticated at the East African Herbarium. The samples were cut into small pieces and dried at room temperature for two weeks before being ground into a fine homogenous powder using an electric mill.

\section{Extraction}

To obtain the extract, $2 \mathrm{~L}$ of methanol was used to soak $400 \mathrm{~g}$ of the sample's powder. The mixture was stirred for $6 \mathrm{~h}$ and left to stand for 24 h. The extract was then soaked through a Whatman's filter paper (No. 1) and the percolate concentrated under reduced pressure and vacuum using R-200 Buchi rotary evaporator (Sigma Aldrich, Switzerland). The concentrate was packed in airtight containers and stored at $4^{\circ} \mathrm{C}$.

*Corresponding authors: Jane W Mbiri, Department of Biochemistry and Biotechnology, School of Pure and Applied Sciences, South Eastern Kenya University, P.O. Box 170-90200, Kitui, Kenya, Tel: +245 704428 355; E-mail: jane7mbiri@gmail.com

Received July 25 2016; Accepted August 19, 2016; Published August 24, 2016

Citation: Mbiri JW, Kasili S, Mbinda W, Kisangau PD, Piero NM (2016) Anti-Pyretic Properties of Methanolic Bark Extracts of Terminalia brownii in Wistar Rats (Rattus novegicus). J Pharmacogn Nat Prod 2: 121. doi:10.4172/2472-0992.1000121

Copyright: @ 2016 Mbiri JW, et al. This is an open-access article distributed under the terms of the Creative Commons Attribution License, which permits unrestricted use, distribution, and reproduction in any medium, provided the original author and source are credited. 


\section{Experimental animals}

The rules for caring and using experimental animals in laboratories [12] and the standards set by the Kenyatta University's ethics committee were keenly followed. 30 adult male Wistar rats weighing 140-180 $\mathrm{g}$ and 2-3 months old [13] were used to evaluate the anti-pyretic properties of $T$. brownii. The rats were placed in standard cages in the KU's animal house where they were left to acclimate for 1 wk under standard laboratory conditions before being used for the experiments. The rats were fed on standard commercial food for rodents and provided with water spontaneously [14].

\section{Anti-pyretic assay}

The antipyretic activity of $T$. brownii's methanolic bark extracts was evaluated on steam-distilled turpentine-induced pyrexia in Rattus novegicus [2]. Aspirin (Zhongshan Yuanhang E-Commercial Co., Ltd., Guangdong, China), dissolved in 10\% DMSO, was used as the standard drug. The rats were divided into six groups with each group having 5 rats. Table 1 displays a summary of the treatments.

In this assay, the weights and initial rectal temperatures of the rats were taken before fever was induced. A properly lubricated thermistor probe of a YB-009 digital thermometer (Shenzhen Osykyoo Technology Co., Ltd., Guadong, China) was imbedded about $3 \mathrm{~cm}$ in to the rectum [15] to take the rectal temperatures. After obtaining the initial rectal temperatures, fever was induced by intraperitoneal administration of $25 \mathrm{ml} / \mathrm{kg}$ bw steam-distilled turpentine.

The rats that experienced a temperature rise by $0.8^{\circ} \mathrm{C}$ after an hour were considered pyretic and therefore given the respective treatments. Fever was not induced in the normal control group but it was induced in the rest of the groups. The normal control group therefore received no treatment, negative control group received $0.5 \mathrm{ml}$ of $10 \%$ DMSO, positive control group received $100 \mathrm{mg} / \mathrm{kg}$ bw Aspirin, experimental group A received $50 \mathrm{mg} / \mathrm{kg}$ bw extract, experimental group B received $100 \mathrm{mg} / \mathrm{kg}$ bw extract and experimental group C received $150 \mathrm{mg} / \mathrm{kg}$ bw extract.

Rectal temperatures were recorded at hourly intervals up to the fourth hour after administration of the treatments. Rectal temperatures before and after treatments were compared by calculating percentage inhibition using the following formula [16];

$$
\frac{B-C n}{B} \times 100
$$

Where,

B: Rectal temperature, $1 \mathrm{~h}$, after turpentine administration

$\mathrm{C}_{\mathrm{n}}$ : Rectal temperature after drug administration

\begin{tabular}{|c|c|c|}
\hline Group & Status & Treatment \\
\hline I & Normal control & None \\
\hline II & Negative control & Turpentine + DMSO \\
\hline III & Positive control & Turpentine $+100 \mathrm{mg} / \mathrm{kg} \mathrm{Aspirin} \mathrm{+} \mathrm{DMSO}$ \\
\hline IV & Experimental group A & Turpentine $+50 \mathrm{mg} / \mathrm{kg}$ extract + DMSO \\
\hline V & Experimental group B & Turpentine + $100 \mathrm{mg} / \mathrm{kg}$ extract + DMSO \\
\hline VI & Experimental group C & Turpentine $+150 \mathrm{mg} / \mathrm{kg}$ extract + DMSO \\
\hline
\end{tabular}

Table 1: Treatment procedure for the evaluation of antipyretic activities of methanolic bark extracts of $T$. brownii in $R$. norvegicus.

\section{Statistical analysis}

The data obtained was recorded and tabulated on Excel spreadsheet and the Minitab statistical software version 17.1.0 was used to analyze the data. The results were presented as mean \pm standard error of mean (SEM). The statistical significance difference among the various groups was evaluated using ANOVA (One Way) and this was followed by Turkey's tests to separate the means and get the precise significant differences among the different groups. Values of $p \leq 0.05$ were regarded as significant.

\section{Results}

The methanolic bark extracts of T. brownii showed antipyretic activity on the turpentine-induced pyrexia in rats and this was indicated by reduction in the rectal temperatures after extract administration (Figure 1, Table 2). In the $1^{\text {st }} \mathrm{h}$, the methanolic bark extracts of $T$. brownii at the dose levels of 50, 100 and $150 \mathrm{mg} / \mathrm{kg}$ bw and aspirin, the reference drug, lowered the elevated rectal temperatures by $1.15 \%$, $2.76 \%, 4.28 \%$ and $4.85 \%$ respectively (Table 2 ). The extract at the three dose levels showed a dose dependent response (Figure 1, Table 2). The antipyretic activity of the extract among the three dose levels was significantly different $(p<0.05$, Table 2$)$. The antipyretic activity of the plant extract at $150 \mathrm{mg} / \mathrm{kg}$ bw dose level was commensurable to that of the reference drug ( $p>0.05$, Table 2$)$. The extract at the three dose levels was significantly different from the negative control group $(p<0.05$, Table 2).

In the $2^{\text {nd }} \mathrm{h}$ after administration of the treatments, the $T$. brownii extract at the dose levels of 50,100 and $150 \mathrm{mg} / \mathrm{kg}$ bw and Aspirin, reference drug, decreased the elevated rectal temperatures by $2.19 \%$, $2.66 \%, 4.38 \%$ and $4.22 \%$ respectively (Figure 1 , Table 2 ). The extract at the three dose levels demonstrated a dose dependent response (Figure 1 , Table 2). The antipyretic activity of the extract at the dose of 150 $\mathrm{mg} / \mathrm{kg}$ bw was significantly different from the antipyretic activity of the extract at 50 and $100 \mathrm{mg} / \mathrm{kg}$ bw dose levels $(p<0.05$, Table 2). In this hour, the antipyretic activity of the extract at 100 and $150 \mathrm{mg} / \mathrm{kg} \mathrm{bw}$ dose levels was as good as that of Aspirin ( $p>0.05$, Table 2). The extract at the three dose levels was significantly different from the negative and normal control groups $(p<0.05$, Table 2$)$.

In the $3^{\text {rd }} \mathrm{h}$, the extract at the dose levels of 50,100 and $150 \mathrm{mg} /$ $\mathrm{kg}$ bw and the reference drug reduced the turpentine-induced pyrexia by $1.98 \%, 2.55 \%, 4.02 \%$ and $4.01 \%$ respectively (Figure 1, Table 2 ). The extract at the three dose levels showed a dose dependent response (Figure 1). The antipyretic activity of the extract at the dose level of $150 \mathrm{mg} / \mathrm{kg}$ bw was significantly different from the antipyretic activity of the extract at the dose levels of 50 and $100 \mathrm{mg} / \mathrm{kg}$ bw $(p<0.05$, Table 2 ). The antipyretic activity of the extract at the dose level of $150 \mathrm{mg} / \mathrm{kg}$ bw was comparable to that of the standard drug $(p>0.05)$. The extract at the three dose levels was significantly different from the negative and normal control groups $(p<0.05$, Table 2$)$.

In the $4^{\text {th }} \mathrm{h}$ after the administration of the treatments, the extract at the dose levels of 50, 100 and $150 \mathrm{mg} / \mathrm{kg}$ bw and the reference drug reduced the elevated rectal temperatures by $2.55 \%, 2.65 \%, 3.76 \%$ and $4.01 \%$ respectively (Figure 1 and Table 2). The extracts of T. brownii at the three dose levels demonstrated a dose dependent response on the turpentine oil-induced pyrexia (Figure 1). The antipyretic activity of the extract at the dose level of $150 \mathrm{mg} / \mathrm{kg}$ bw was significantly different from the antipyretic activity of the extract at the dose level of $50 \mathrm{mg} /$ $\mathrm{kg} \mathrm{bw}(p<0.05)$. Compared to aspirin and the extract at $100 \mathrm{mg} / \mathrm{kg} \mathrm{bw}$ dose level, the extract at the dose level of $150 \mathrm{mg} / \mathrm{kg}$ bw did not show a significant difference ( $p>0.05$, Table 2$)$. The extract at the three dose levels was significantly different from the negative and normal control 


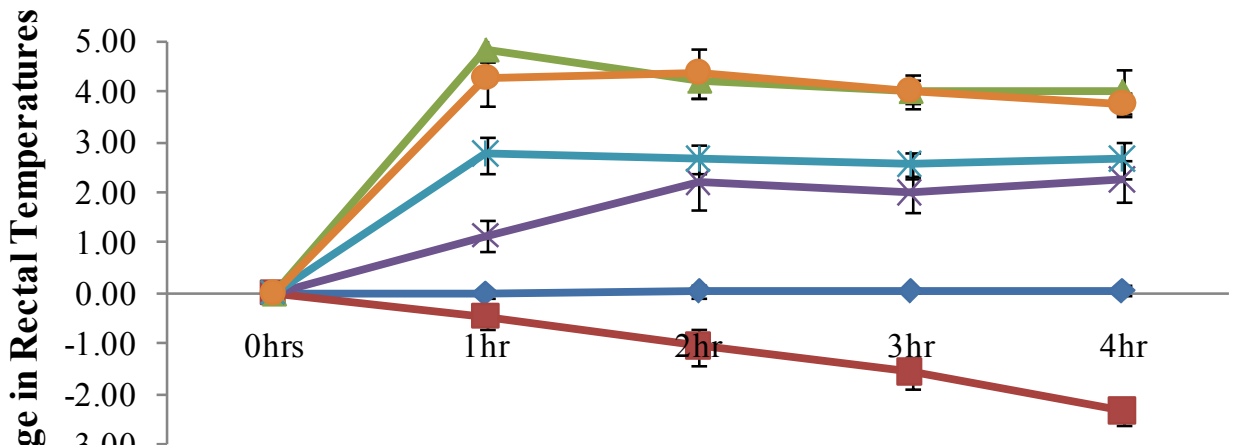

Time After Treatment (Hrs)

Normal Control

$\leftarrow 50 \mathrm{mg} / \mathrm{kg} \mathrm{bw}$

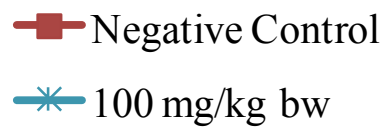

\section{- Positive Control}

$-150 \mathrm{mg} / \mathrm{kg}$ bw

Figure 1: Antipyretic activity of the methanolic bark extracts of T. brownii in R. novegicus.

\begin{tabular}{|c|c|c|c|c|c|c|}
\hline \multirow{2}{*}{ Group } & \multirow{2}{*}{ Treatment } & \multicolumn{5}{|c|}{$\%$ Change in Rectal Temperatures after Treatment } \\
\hline & & $\mathbf{O H}$ & $1 \mathrm{~h}$ & $2 \mathrm{~h}$ & $3 \mathrm{~h}$ & $4 \mathrm{~h}$ \\
\hline Normal Control & DMSO & $\begin{array}{c}100.00 \pm 0.00 \\
(0.00 \%)\end{array}$ & $\begin{array}{c}100.00 \pm 0.09^{\mathrm{ab}} \\
(0.00 \%)\end{array}$ & $\begin{array}{c}99.95 \pm 0.13^{\mathrm{a}} \\
(0.05 \%)\end{array}$ & $\begin{array}{c}99.95 \pm 0.05^{\mathrm{b}} \\
(0.05 \%)\end{array}$ & $\begin{array}{c}99.95 \pm 0.10^{\mathrm{b}} \\
(0.05 \%)\end{array}$ \\
\hline Negative Control & Turpentine + DMSO & $\begin{array}{c}100.00 \pm 0.00 \\
(0.00 \%)\end{array}$ & $\begin{array}{c}100.47 \pm 0.23^{a} \\
(-0.47 \%)\end{array}$ & $\begin{array}{c}101.04 \pm 0.36^{a} \\
(-1.05 \%)\end{array}$ & $\begin{array}{c}101.57 \pm 0.30^{\mathrm{a}} \\
(-1.57 \%)\end{array}$ & $\begin{array}{c}102.35 \pm 0.24^{a} \\
(-2.35 \%)\end{array}$ \\
\hline Positive Control & Turpentine + Asprin + DMSO & $\begin{array}{c}100.00 \pm 0.00 \\
(0.00 \%)\end{array}$ & $\begin{array}{c}95.42 \pm 0.23^{\mathrm{d}} \\
(4.85 \%)\end{array}$ & $\begin{array}{c}95.78 \pm 0.32^{\mathrm{cd}} \\
(4.22 \%)\end{array}$ & $\begin{array}{c}95.99 \pm 0.34^{\mathrm{d}} \\
(4.01 \%)\end{array}$ & $\begin{array}{c}95.99 \pm 0.46^{d} \\
(4.01 \%)\end{array}$ \\
\hline Experimental Group A & Turpentine + $50 \mathrm{mg} / \mathrm{kg}+\mathrm{DMSO}$ & $\begin{array}{c}100.00 \pm 0.00 \\
(0.00 \%)\end{array}$ & $\begin{array}{c}98.90 \pm 0.29^{b} \\
(1.15 \%)\end{array}$ & $\begin{array}{c}97.81 \pm 0.50^{\mathrm{b}} \\
(2.19 \%)\end{array}$ & $\begin{array}{c}98.02 \pm 0.37^{c} \\
(1.98 \%)\end{array}$ & $\begin{array}{c}97.76 \pm 0.40^{c} \\
(2.25 \%)\end{array}$ \\
\hline Experimental Group B & Turpentine + $100 \mathrm{mg} / \mathrm{kg}+\mathrm{DMSO}$ & $\begin{array}{c}100.00 \pm 0.00 \\
(0.00 \%)\end{array}$ & $\begin{array}{c}97.24 \pm 0.35^{c} \\
(2.76 \%)\end{array}$ & $\begin{array}{c}97.34 \pm 0.29^{\mathrm{bc}} \\
(2.66 \%)\end{array}$ & $\begin{array}{c}97.45 \pm 0.27^{c} \\
(2.55 \%)\end{array}$ & $\begin{array}{c}97.35 \pm 0.35^{\mathrm{cd}} \\
(2.65 \%)\end{array}$ \\
\hline Experimental Group C & Turpentine + $150 \mathrm{mg} / \mathrm{kg}+\mathrm{DMSO}$ & $\begin{array}{c}100.00 \pm 0.00 \\
(0.00 \%)\end{array}$ & $\begin{array}{c}95.72 \pm 0.55^{d} \\
(4.28 \%)\end{array}$ & $\begin{array}{c}95.62 \pm 0.48^{d} \\
(4.38 \%)\end{array}$ & $\begin{array}{c}95.99 \pm 0.23^{d} \\
(4.02 \%)\end{array}$ & $\begin{array}{c}96.24 \pm 0.26^{d} \\
(3.76 \%)\end{array}$ \\
\hline
\end{tabular}

The values were expressed as Mean \pm SEM for five rats per group. Statistical comparisons were done within a column and values with a similar superscript are not significantly different by ANOVA followed by Tukey's post hoc test $(p>0.05)$. Percentage reduction in rectal temperature is given within the brackets. Turpentine oil=25 ml/ $\mathrm{kg} \mathrm{BW}$; DMSO=10\%; Asprin=15 mg/kg

Table 2: Antipyretic activity of methanolic bark extracts of $T$. brownii in R. novegicus.

groups ( $p<0.05$, Table 2 ). The extract at the dose level of $150 \mathrm{mg} / \mathrm{kg}$ bw exhibited the highest antipyretic activity in all the four hours.

\section{Discussion}

Turpentine oil is an exogenous pyrogen that is widely used to induce fever in experimental rats and mice [17]. Other exogenous pyrogens that have been used to induce fever include; brewer's yeast [18], Lipopolysaccharides [19] and polyinosinic: Polycytidylic acid [20]. Steam-distilled turpentine induces pyrexia faster [within an hour or two], experimental animals acquire a higher tolerance to it than to other exogenous pyrogens and produces a steady pyrexia trend [2]. It is against this background that turpentine oil was chosen as a model for screening for the antipyretic activity of the methanolic bark extracts of $T$. brownii in this study. In the present study, crude turpentine was distilled to eliminate impurities and obtain pure turpentine oil. These impurities could have interfered with the tests or even killed the experimental rats as it was observed in the pilot study.

The most commonly prescribed drugs for the management of pyrexia are the NSAIDs such as diclofenac, aspirin and ibuprofen [17]. NSAIDs inhibit the activity of the enzyme Cyclooxygenase (COX-2) whose function is to convert arachidonic acid to $\mathrm{PGE}_{2}$ [21] $\mathrm{PGE}_{2}$ are the main fever mediators [2]. The findings of this study therefore suggest that the methanolic bark extract of T. brownii was able to inhibit the activity of COX-2 enzyme hence its antipyretic activity.

The methanolic bark extracts of $T$. brownii demonstrated a significant antipyretic activity in all the four hours after the administration of the treatments. These results relate to the findings of [22] who demonstrated a significant antipyretic activity of some medicinal plants from Cholistan desert Pakistan, [23] who affirmed significant antipyretic properties of virgin coconut oil and [24] who showed that Azima tetracantha's friedelin possess significant antipyretic effect. The dose levels of the extract used in the present study to evaluate the antipyretic activity of T. brownii were 50, 100 and 150 $\mathrm{mg} / \mathrm{kg}$ bw and were similar to those used $[17,25,26]$. The methanolic bark extracts of $T$. brownii exhibited a dose-dependent response on the turpentine oil-induced pyrexia in the experimental rats. These findings were consistent with the findings of other studies on medicinal plants from Cholistan desert Pakistan [22], Piper cubeba L. essential oil [5] and ethyl acetate roots extracts of Ocimum sanctum [27]. 
The extract at the dose level of $150 \mathrm{mg} / \mathrm{kg}$ bw demonstrated the highest antipyretic activity compared to the dose levels of 50 and $100 \mathrm{mg} / \mathrm{kg}$ bw in all the four hours after the administration of the treatments. This can be explained by the possible existence of an adequate concentration of the active principle(s) in the dose level of $150 \mathrm{mg} / \mathrm{kg}$ bw in comparison to the lower dose levels of the extract. It can also be explained by the quick metabolism and expulsion of the effective principle(s) present in inadequate concentrations in the lower dose levels of the extract. The reference drug, Aspirin, demonstrated the highest antipyretic activity compared to the three dose levels of the extract. This can be suggested to be as a result of the reference drug exhibiting a better blockage of the biosynthesis of prostaglandins than the extract [17].

The extract at the dose levels of 100 and $150 \mathrm{mg} / \mathrm{kg}$ bw and the standard drug achieved their maximum antipyretic activity in the $1^{\text {st }}$, $2^{\text {nd }}$ and $3^{\text {rd }} \mathrm{h}$ respectively and then their activity decreased subsequently. This could probably be due to the metabolism and excretion of the respective treatments. However, the extract $50 \mathrm{mg} / \mathrm{kg}$ bw dose level achieved its maximum activity at the fourth hour. This could be due to the gradual diffusion of the functional principle(s), present in very low concentrations in the extract, across the cell membrane into the peritoneal cavity [28].

Several studies have revealed a number of phytochemical secondary metabolites present in T. brownii. The phytochemical screening of methanolic bark extracts of $T$. brownii conducted by Wanja et al. [29] affirmed the presence of terpenoids, phenols, steroids, saponins and flavonoids in that extract. Methanolic leaf extracts of T. brownii have been reported to possess phytosterols, coumarins, flavonoids, tannins, polyphenols, and saponins [30]. Fourier Transform Infrared (FTIR) spectroscopy of crude dry powder of $T$. brownii revealed the presence of saponins [31]. Phytochemical screening of ethyl acetate stem bark extract of T. brownii revealed the presence of $3-O-\beta-\mathrm{D}$ glucopyranosyl- $\beta$-sitosterol, an oleanane-type triterpenoid, seven ellagic acid derivatives and seven known triterpenoids [32]. Ethyl acetate and $\mathrm{n}$-hexane extracts of T. brownii revealed the presence of five compounds; arjungenin, $\beta$-sitosterol, betulinic acid, monogynol A and stigmasterol [33].

The anti-pyretic activity of the methanolic bark extract of $T$. brownii could therefore be attributed to the activity of one or more of the phytochemical secondary metabolites that have been reported to be present in this tree. Steroids and terpenoids have been reported to inhibit the activity of prostaglandin synthetase, the enzyme that stimulates the production and release of prostaglandins, the primary mediator in fever induction [34]. Flavonoids can inhibit fever in two ways; by decreasing the release of arachidonic acid or by interfering with the eicosanoids biosynthesis pathways involved in fever production [6]. These two actions in turn suppress mediators like prostaglandins responsible for fever [6]. Saponins also have antipyretic activity [35]. The present study therefore suggests that the methanolic bark extracts of $T$. brownii demonstrated an anti-pyretic activity due to the presence of steroids, terpenoids, flavonoids and saponins that have been revealed to possess anti-pyretic activity.

\section{Conclusion}

Significant anti-pyretic activity of the methanolic bark extract of $T$. brownii was demonstrated in the present study. This study concludes that the anti-pyretic activity of the extract could be due to the presence of bioactive principles with a pharmacological potential. The extract demonstrated a dose-dependent response to the turpentine oil-induced fever with its highest anti-pyretic activity at $150 \mathrm{mg} / \mathrm{kg}$ bw dose. The anti-pyretic activity of the extract at $150 \mathrm{mg} / \mathrm{kg}$ bw dose level was similar to the anti-pyretic activity of Aspirin. The barks of T. brownii can therefore be considered as a probable candidate that can be used to develop a neoteric anti-pyretic formulation that is more affordable, readily available and has less adverse effects. The present study therefore supports and provides a scientific validation of the local use of T. brownii as a remedy for fever.

\section{Acknowledgement}

The authors are thankful to the Department of Biochemistry and Biotechnology, School of Pure and Applied Sciences, Kenyatta University, Nairobi, Kenya, fo availing their facilities to carry out this research.

\section{References}

1. Shukla S, Mehta A (2015) In vivo anti-inflammatory, analgesic and antipyretic activities of a medicinal plant, Caesalpinia bonducella F. Pak J Pharm Sci 28 1517-1521.

2. Kamau JK, Nthiga PM, Safari VC, Njagi SM, Mwonjoria JK, et al. (2016) Antipyretic Properties of Methanol Stem Bark Extracts of Acacia hockii De Wild and Kigelia africana (Lam) Benth in Wistar Rats. J Pharmacogn Nat Prod 2: 118.

3. Saper CB, Breder CD (1994) The neurologic basis of fever. N Engl J Med 330 1880-1886.

4. Watson R, Fawcett TN, Fawcett JN (2003) Pathophysiology, Homeostasis and Nursing. Psychology Press.

5. Mothana R, Alsaid M, Khaled JM, Alharbi NS, Alatar A, et al. (2016) Assessment of antinociceptive, antipyretic and antimicrobial activity of Piper cubeba L. essential oil in animal models. Pak J Pharm Sci 29: 671-677.

6. Subedi NK, Rahman SM, Akbar MA (2016) Analgesic and antipyretic activities of methanol extract and its fraction from the root of Schoenoplectus grossus. Evidence-Based Complementary and Alternative Medicine 28: 1-8.

7. Amaral MIG, Silva MR, Aquino-Neto PF, Teixeira-Neto BA, Moura CT, et al. (2007) Biologica and Pharmaceutical Bulletin 30: 12-17.

8. Bordgers R, Nascimento MVM, de Carvalho AAV, Valadares MC, de Paula JR et al. (2013) Antinociceptive and anti-inflammatory activities of the ethanolic extract from synadenium umbellatum pax. (Euphorbiaceae) leaves and its fractions. Evidence-based Complementary and Alternative Medicine 2013.

9. Robinon MR, Zhang X (2011) The World Medicine Situation (Traditiona Medicines: Global Situation, Issues and Challenges). Geneva, WorldHealth Organization, Geneva, Switzerland.

10. Mbwambo ZH, Moshi MJ, Masimba PJ, Kapingu MC, Nondo RS (2007) Antimicrobial activity and brine shrimp toxicity of extracts of Terminalia brownii roots and stem. BMC Complementary and Alternative Medicine 7: 1-5

11. Schmidt LH (2010) Terminalia brownii Fresen. Seed Leaflet 148.

12. Wolfensohn S, Lloyd M (1998) Handbook of laboratory animal management and Welfare $\left(2^{\text {nd }}\right.$ edn.) Blackwell science Ltd, Oxford UK pp: 169-216.

13. Khan H, Saeed M, Gilani AH, Muhammad N, Haq IU, et al. (2013) Antipyretic and anticonvulsant activity of Polygonatum verticillatum: comparison of rhizomes and aerial parts. Phytother Res 27: 468-471.

14. Vogel HG (2002) Drug discovery and evaluation: pharmacological assays Springer-science and Business Media.

15. Grover JK (1990) Experiments in Pharmacy and Pharmacology. CBS Publishe and Distributor, Shahdara Delhi, India 1: 155-160.

16. Hukkeri VI, Nagathan CV, Karadi RV (2006) Antipyretic and wound healing activities of Moringa oeifera in rats. Indian J Pharm Sci 68: 124-126.

17. Maina GS, Kelvin JK, Maina MB, Muriithi NJ, Kiambi, et al. (2015) Antinociceptive properties of dichloromethane: methanolic leaf and root bark extracts of Carissa edulis in rats. J Phytopharmacol 4: 106-112.

18. Safari VZ, Kamau JK, Nthiga PM, Ngugi MP, Orinda G, et al. (2016a) Antipyretic, Antiinflammatory and Antinociceptive Activities of Aqueous Bark Extract of Acacia Nilotica (L.) Delile in Albino Mice. J Pain Manag Med 2: 1-7.

19. Anochie IP (2013) Mechanisms of fever in humans. Int J Microbiol Immuno Res 2: 37-43. 
Citation: Mbiri JW, Kasili S, Mbinda W, Kisangau PD, Piero NM (2016) Anti-Pyretic Properties of Methanolic Bark Extracts of Terminalia brownii in Wistar Rats (Rattus novegicus). J Pharmacogn Nat Prod 2: 121. doi:10.4172/2472-0992.1000121

20. Fortier M, Kent S, Ashdown H, Poole S, Boksa P, et al. (2004) The Viral Mimic, Polyinosinic; Polycytidylic acid, Induces Fever in Rats via an IL-1DependentMechanism. American Journal of Physiology-Regulatory, Integrative and Comparative Physiology 287: 759-66.

21. Gustafson-Svärd C, Lilja I, Hallböök O, Sjödahl R (1997) Cyclo-oxygenase and colon cancer: clues to the aspirin effect? Annals of Medicine 29: 247-252.

22. Alam MK, Ahmed S, Anjum S, Akram M, Shah SMA, et al. (2016) Evaluation of antipyretic activity of some medicinal plants from Cholistan desert Pakistan. Pak J Pharm Sci 29: 529-33.

23. Intahphuak S, Khonsung P, Panthong A (2010) Anti-inflammatory, analgesic, and antipyretic activities of virgin coconut oil. Pharm Biol 48: 151-157.

24. Antonisamy P, Duraipandiyan V, Ignacimuthu S (2011) Anti-inflammatory, analgesic and antipyretic effects of friedelin isolated from Azima tetracantha Lam in mouse and rat models. J Pharm Pharmacol 63: 1070-1077.

25. Afsar T, Khan MR, Razak S, Ullah S, Mirza B (2015) Antipyretic, antiinflammatory and analgesic activity of Acacia hydaspica R. Parker and its phytochemical analysis. Biomedical Central Complementary and Alternative Medicine 15: 136-151.

26. Akuodor GC, Essien AD, Essiet GA, Essien DO, Akpan JL, et al. (2013) Evaluation of antipyretic potential of pseudocedrela kotschyi schweint. harms (meliaceae). European Journal of Medicinal Plants 3: 105-113.

27. Kumar A, Agarwal K, Maurya AK, Shanker K, Bushra U, et al. (2015) Pharmacological and phytochemical evaluation of Ocimum sanctum root extracts for its anti-inflammatory, analgesic and antipyretic activities. Pharmacogn Mag 11: 217-224.

28. Hossain E, Mandal SC, Gupta JK (2011) Phytochemical screening and in-vivo antipyretic activity of the methanol leaf-extract of Bombax malabaricum DC (Bombacaceae). Tropical Journal of Pharmaceutical Research 10: 55-60.
29. Wanja MJ, Kasili S, Patrick K, Mbinda W, Piero NM (2016) Anti- inflammatory properties of methanolic bark extracts of Terminalia brownii in Wistar albino rats. International Journal of Current Pharmaceutical Research 8.

30. Periasamy P, Alemayehu Y, Tarekegn W, Sintayehu B, Gebrelibanos M, et al. (2015) Evaluation of in Vivo Central Analgesic Activity and Prelimnary Phytochemical Screening of Methanolic Extract of Terminalia brownii Leaves. International Journal of Pharmacy and Biological Sciences 5: 49-53.

31. Kareru PG, Keriko JM, Gachanja AN, Kenji GM (2008b) Direct Detection of Triterpenoid Saponins in Medicinal Plants. African Journal of Tradition, Complementary and Alternative Medicines 5: 56-60.

32. Machumi F, Midiwo JO, Jacob MR, Khan SI, Tekwani BL, et al. (2013) Phytochemical, antimicrobial and antiplasmodial investigations of Terminalia brownii. Nat Prod Commun 8: 761-764.

33. Opiyo S, Manguro L, Owuor P, Ochieng C, Ateka E, et al. (2011) Antimicrobia compounds from Terminalia brownii against sweet potato pathogens. Nat Prod J 1: 116-120.

34. Niazi J, Gupta V, Chakarborty P, Kumar P (2010) Anti-inflammatory and antipyretic activity of Aleuritis moluccanaleaves. Asian Journal of Pharmaceutical Clinical Research 3: 35-37.

35. Zakaria ZA, Wen LY, Abdul RN, Abdul AH, Sulaiman MR, et al. (2007) Antinociceptive, anti-inflammatory and antipyretic properties of the aqueous extract of Bauhinia purpurea leaves in experimental animals. Medical Principles and Practice 16: 443-449. 